\title{
A Comparison of Economic Performance of Emerging and Established Fishing Enterprises at Lake Kariba, Zimbabwe
}

\author{
Kefasi Nyikahadzoi ${ }^{1}$ \& Loveness Nyikahadzoi ${ }^{2}$ \\ ${ }^{1}$ Centre for Applied Social Science, University of Zimbabwe, Zimbabwe \\ ${ }^{2}$ Accountancy Department, University of Zimbabwe, Zimbabwe \\ Correspondence: Kefasi Nyikahadzoi, Centre for Applied Social Sciences, University of Zimbabwe, Zimbabwe. \\ Tel: 263-430-7134. E-mail: knyika@gmail.com
}

\author{
Received: February 18, 2013 Accepted: March 23, 2013 Online Published: April 27, 2013 \\ doi:10.5539/ass.v9n5p226 URL: http://dx.doi.org/10.5539/ass.v9n5p226
}

\begin{abstract}
This research compares the economic performance of established and new entrants in kapenta fishing industry at Kariba in Zimbabwe. The paper uses primary data to compare profitability, technical and marketing ecomonies of scale between established and emerging companies. The results show that both company types have positive net profit. Emerging companies with generally less fishing units have higher technical economies of scale than establsihed ones. Emerging companies use illegal fishing practices to catch more fish using less operating costs. The results show that established companies have higher marketing economies of scale largely because of contractual arrangements established over time.
\end{abstract}

Keywords: economic, performance, kapenta, fishing, Zimbabwe, emerging and established company

\section{Introduction}

Lake Kariba was built in 1958 by damming the Zambezi River. The inland Lake was created as a strategy to alleviate shortages of electricity within the Rhodesia and Nyasaland Federation particularly for Southern Rhodesia (now Zimbabwe) and Northern Rhodesia (now Zambia). However, new secondary resource uses and activities ensued and one of the most thriving is the pelagic semi-industrialized fishing industry. The industry is based on the exploitation of Limnothrissa miodon, a fresh water sardine, locally known as Kapenta.

The fishery commenced in 1974 when Zimbabwe was under colonial rule. From the onset, the criteria used to allocate Kapenta fishing rights favoured white commercial farmers against the black peasant farmers. Thus prior to independence, established entrepreneurs built big Kapenta fishing companies some with a minimum of five fishing boats. At independence in 1980, the Government of Zimbabwe had a challenge of eliminating extreme inequalities generated by discriminatory regulations created during the colonial era (1890 to 1980) (Government of Zimbabwe, 1981). The government embarked on strategies designed to equitably redistribute access rights to the fishery and promote sustainable use of the resource. State redistributed access rights to the resource from established companies to emerging black entrepreneurs. Government preferred to broaden participation to a large number of applicants. New entrants were getting a fishing license that allowed them to use between 1 and 4 fishing vessels. However, despite the government's redistribution efforts, many established companies managed to remain with more than four fishing vessels. Majority of them are still operating as many as eleven fishing vessels. Although government redistributed access rights, it made no similar efforts to level off differences in experience and skills between small new entrants and the established companies. This paper uses business economic concepts to determine the difference in performance of emerging business enterprises when compared to the established ones.

\section{Theoretical Framework}

The short-term objective of all business ventures is to make sure that contribution margins (the amount remaining from sales after variable costs have been deducted) are exceeding operating costs (Nelson and Robinson 2009). To continue operating in the short run, a company is expected to earn positive contribution margins (Kaplan and Cooper 1998). The non-negative profit (or situation where all fixed costs are covered) is the pre-requisite for the long-term viability of any company. Companies with negative gross profit are clearly not viable, especially if this 
situation continues for some time. Fishing companies with positive operating profit but negative net profit may be undergoing temporary problems (for example, a bad fishing season) or living off their capital.

The concept of economies of scale is premised on the understanding that a large company is inherently more efficient than a smaller company (Burt \& Sparks, 2003). In other words, average costs of producing one unit of goods decreases as the volume of productivity increases. (Varian, 1996; Cinquini \& Mitchell, 2005). Economic theory and empirical evidence suggest that one of the dominant economic factors that greatly influence the success of a firm is the presence of economies of scale (Williamson 1996). The assumption is that production at a large scale (more output) can be achieved at a lower cost. If a firm attains economies of scale, its (average) cost of production falls when it increases scale of operation and has fewer transaction costs (Coase, 1960; Porter, 1990). Using this argument, one would also expect large fishing companies to produce and distribute a unit of Kapenta at a lower average cost (in production and marketing) than small fishing companies largely owned by emerging business entrepreneurs. In economic terms, a viable size of company is one that is able to realise economies of scale (Varian, 1996).

\section{Research Methods}

The paper seeks to investigate the challenges that emerging fishing companies are facing in comparison to established ones that have been in operation longer. To enable us to undertake such an analysis, we required some economic data. Zimbabwe Parks and Wildlife Management Authority, a government department responsible for managing and controlling wildlife management, had some data on catch and price upon which revenue could be estimated. This data set was complemented with some economic data that we collected during the year 2010 . Admittedly, such an approach failed to provide an analysis of how economic performances have changed over time as circumstances were changing. Given the data limitations, the study therefore relied on fishing companies' views regarding the directions of change. Sanyati and Bumi basins as study sites were selected because they are easily accessible by both boat and road. Figure 1 shows the locations of the two study sites (marked 4 and 5).

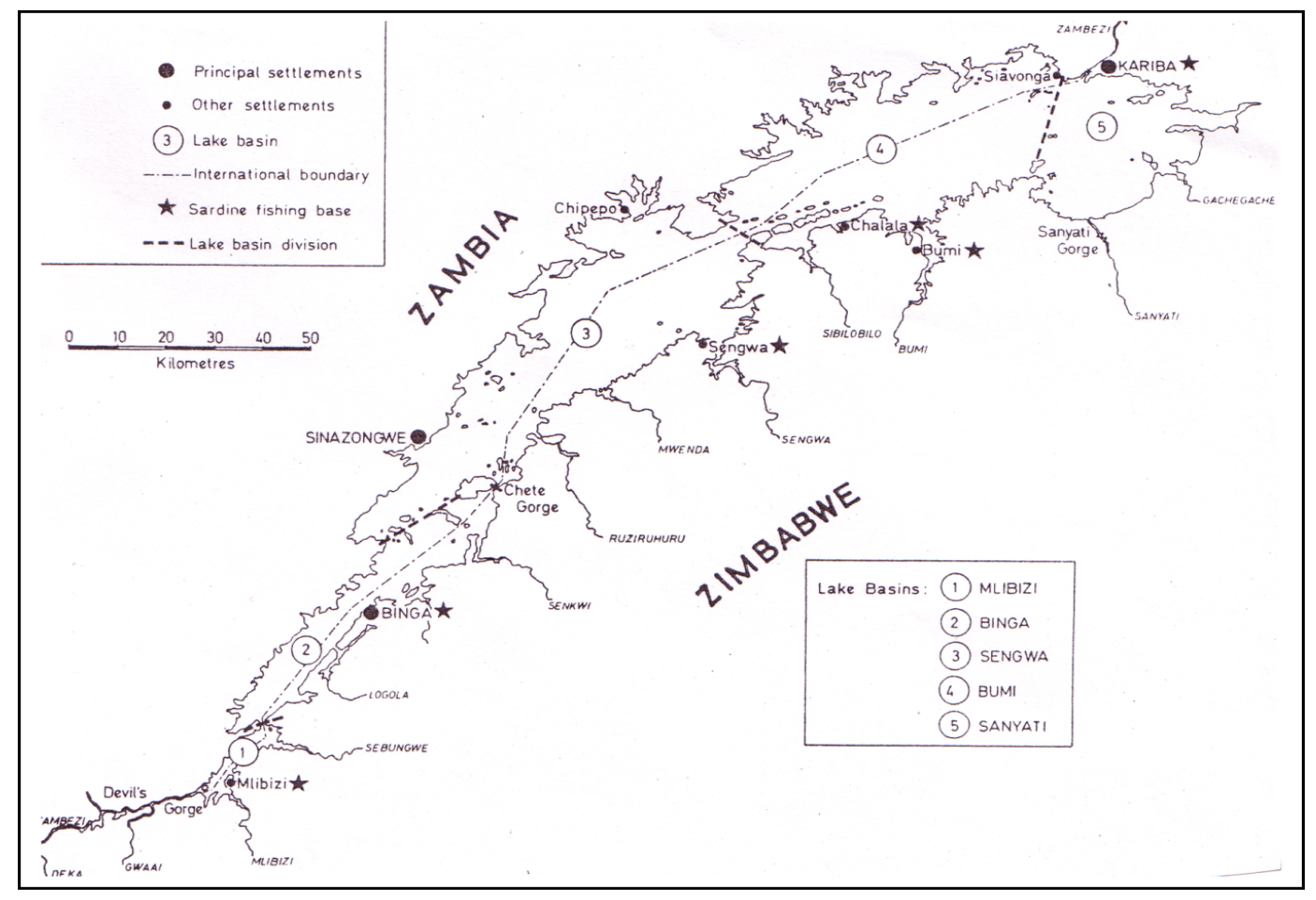

Figure 1. Map of Kariba showing locations of fishing basins

The population was divided into three groups (strata). The three groups were categorised in terms of the company sizes. As a proxy for size, we used the number of fishing vessels owned by a company. The size of the sample in each category was weighted against the total number of companies in the category. Table 1 below shows sampling sizes. 
Table 1. Samples used for economic data collection

\begin{tabular}{llllll}
\hline Size of Company & \multicolumn{2}{l}{ Bumi (Totals) } & Sample Sanyati (Totals) & Sample Ownership \\
\hline Small (1 - 3 vessels) & 5 & 4 & 16 & 7 & Purely emerging \\
Medium (4 and 5 vessels) & 6 & 3 & 8 & 4 & Both emerging and established \\
Big (6 and above vessels) & 7 & 4 & 7 & 6 & Purely established \\
Total & 18 & 10 & 31 & 17 & \\
\hline
\end{tabular}

The Table shows that the $1-3$ category is comprised of purely emerging companies, the $4-5$ category is a mixture of emerging and established companies. The above 6 fishing vessels category is comprised of purely established companies. Within each stratum, simple random sampling was used to choose companies for interview.

\subsection{Data Analysis}

The data were analysed using STATA version 11.2. The descriptive analysis covers means, to give a statistical summary of important indicators. The results are presented in Table 2 . A chi squared test was used to measure the independence of emerging and established companies across fishing basins. Also $t$ statistics was used to measure the differences between means. In order to capture the importance of length of operation as a determinant of performance, we use the small and the large categories in Table 1 above.

\section{Research Results}

The results are presented in Tables 2, 3, 4 and 5 below.

\subsection{Contribution Margins and Net Profits}

Table 2 shows the economic performance of different companies in the two locations. It expresses the cost items, as percentages of total annual revenue. From Table 2, all companies were making positive gross profits during 2010. Even using economic theory of the firm we could also see that all the Kapenta fishing companies were making positive profits as the average price (Table 3) was above the Average Total Costs (ATC as shown in Table 5) Contribution margins were over 50 percent of total revenue for most companies, with the exceptions of emerging companies in Bumi that recorded 45 percent during the year 2010. Table 2 shows that gross profits ranged from 39 percent of total revenue for emerging companies in Bumi basin to 70 percent for established companies in the same basin. While it appears as though emerging companies (all of them cooperatives) were making profits, it is important to note that their per capita income from fishing was very low as the profit was shared among many members in all cases not less than twelve per cooperative.

Table 2. Percentage of variable and fixed costs to total revenue for 2010

\begin{tabular}{lcccc}
\hline Location & \multicolumn{2}{c}{ Sanyati } & \multicolumn{2}{c}{ Bumi } \\
\hline Company size & Emerging & Established & Emerging & Established \\
Revenue & $100 \%$ & $100 \%$ & $100 \%$ & $100 \%$ \\
\% of fuels and oils costs & 22 & 21 & 33 & 15 \\
\% of maintenance costs & 5 & 3 & 11 & 6.8 \\
\% of Salt costs & 1.9 & 1.4 & 2.7 & 1.6 \\
\% of Packaging costs & 0.4 & 1.7 & 2.8 & 0.9 \\
\% of Labour costs & 5.6 & 4.8 & 4.2 & 1.7 \\
\% of Marketing costs & 0.3 & 1.4 & 2.0 & 1.2 \\
\% of Total Variable costs & 35 & 33 & 54 & 27.6 \\
\% Contribution Margins & 65 & 66 & 45 & 72 \\
\% of Insurance costs & 4 & 3.3 & 0.2 & 0.1 \\
\% of Rentals costs & 1 & 1.9 & 0.2 & 0.03
\end{tabular}




\begin{tabular}{lcccc} 
\% of Interest paid & 0.5 & 2.6 & 0 & 0 \\
\% of Salaries & 8.4 & 3 & 5 & 1.6 \\
\% of License fee & 0.4 & 0.5 & 0.2 & 0.1 \\
\% of Bills & 1.3 & 12.8 & 0.5 & 0.1 \\
\% of Total fixed costs & 15 & 24 & 6.2 & 2.0 \\
\% of Total Costs & 50 & 56 & 61 & 29 \\
\% of Gross Result & 49 & 43 & 39 & 70 \\
\hline
\end{tabular}

Comparison by size: $\mathrm{p}$ value of Chi squared $=0.001$ for Sanyati and $\mathrm{p}$ value $=0.01$ for Bumi

\subsection{Variations in Ability to Maximise Net Profit}

Using Chi squared we note that there is a notable difference in performance between established companies in Bumi and their counterparts in the Sanyati basin. Table 2 shows that emerging companies had a gross result of $39 \%$ compared to $70 \%$ for established companies although they are operating from the same location. Table 2 also shows that while established companies in Bumi had $70 \%$ of total revenue as gross profit their counterparts in the Sanyati basin had $43 \%$ in the same year. Similarly, emerging companies in Sanyati had a gross result of $49 \%$ of total revenue compared to $39 \%$ for established companies in the same basin. During the feedback meetings, operators gave three explanations for the variations in ability to maximize net profit between companies of identical sizes operating in different locations.

\subsubsection{Different Company Sizes in the Same Location}

Some fishing companies attributed the variations in economic performance of different companies operating from the same location to differences in the ability to smoothen bad and good catches caused by temporal and spatial variations in resource abundance. Established companies in Bumi had access to a larger fishing area (including the Sengwa basin) with diverse ecological characteristics. Table 3 shows that the mean catch levels of established companies were statistically (using t statistics) higher than those of emerging companies for the three consecutive years than those realized by emerging companies. It would appear that only the established big companies were well positioned to smoothen bad and good catches caused by spatial variations in resource abundance. They had the capacity to modify operating strategies to suit temporal and spatial variations of the fishery as they were able to take advantage of the ecological diversity and abundance of the resource in adjacent basins. This could be one of the reasons that accounted for wide variations in net income between emerging and established companies operating in the same basin.

Table 3. Catch Variations by size and basin during 2010 (in tonnes)

\begin{tabular}{lcccc}
\hline Location & \multicolumn{2}{c}{ Sanyati } & \multicolumn{2}{c}{ Bumi } \\
\hline Company size & Emerging & Established & Emerging & Established \\
2008 & 25.6 & $103.4^{*}$ & 29.1 & $90.9^{* *}$ \\
2009 & 35.9 & $122.0^{* *}$ & 33.5 & $109.2^{* *}$ \\
2010 & 42.8 & $132.90^{* * *}$ & 35.6 & $120.6^{* * *}$ \\
\hline
\end{tabular}

Comparing emerging and established: Significant levels $* * *=1 \%, * *=5 \%, *=10 \%$.

\subsubsection{Same Company Sizes and Different Locations}

Although established companies in Sanyati had higher average catches compared to their counterparts in Bumi, the product quality was different. Quality of Kapenta was also highlighted as an important factor that could explain spatial differences in their ability to maximise net profit among companies of the same size. The quality of Kapenta from Bumi was generally high and hence fetched more money on the market. One Kapenta fishing company manager alleged that one kilogramme of Kapenta from Sanyati had five times more fish than that from the Bumi area. 
The spatial variations in capacity to maximise net profit could also be accounted for by wide differences between prices paid by the final consumer and those received by the primary producer. Table 4 presents spatial variations in prices of Kapenta for 2009. Most established companies in Bumi were able to achieve higher earnings through capitalisation on informational advantage in pricing because their operations were geographically dispersed.

Table 4. Local variations in price of Kapenta (2009 prices)

\begin{tabular}{lcccc}
\hline Location & \multicolumn{2}{c}{ Bumi } & \multicolumn{2}{c}{ Sanyati } \\
\hline Company sizes & Emerging & Established & Emerging & Established \\
Average Producer Price $(\$ / \mathrm{kg})$ & 4.5 & 7.00 & 4.5 & 5.00 \\
Transport and associated Costs $(\$ / \mathrm{kg})$ & 0.75 & 0.68 & 0.50 & 0.55 \\
Tax $(\$)$ & 0.15 & 0.15 & 0.15 & 0.15 \\
Average Consumer Price $(\$ / \mathrm{kg})$ & 8.00 & 8.00 & 8.00 & 8.00 \\
\hline
\end{tabular}

Established fishing companies in Bumi also marketed their Kapenta at retail price in urban areas compared to their counterparts. It was observed that all the established companies opened up their own retail outlets in Zimbabwe's major cities. These companies received 80 percent of the price paid by the final consumer, a strategy that resulted in relatively large gross profits (see Table 4). The ability to by pass the middlemen enabled these companies to realise relatively higher profit margins (see Table 2). Therefore physical isolation, though it worked against small-scale companies in Bumi, was actually a blessing in disguise for established companies in the same basin.

\subsubsection{Emerging Companies Operating from Different Location}

Small companies in Sanyati were doing well in terms of maximising net profit when compared to their counterparts in Bumi. Table 2 shows that emerging companies in Sanyati had 49 percent during 2010 of total revenue as net profit while those in Bumi had 39 percent during the same year. One of the reasons for this variation could be the difference in price that the companies in the two areas they sell their product at. On average, emerging companies in Bumi area received a much smaller proportion ( 45 percent) of the price paid by the final consumer of Kapenta while companies in Kariba received 48 percent of the price paid by the final consumer (Table 4). About 15 percent and 11 percent of the variations between producer price and consumer price was accounted for by transport costs in Bumi (emerging companies) and Sanyati (emerging companies), respectively.

On average, the producer prices prevailing at the two places differed significantly. The remoteness, underdeveloped infrastructure, inefficient transport services and other transaction costs prevented many traders from buying Kapenta from Bumi area. Therefore, lack of competition among buyers had an effect on the price received by emerging companies. In Bumi the bargaining power of a few buyers who visited the area was strengthened by the fact that buyers came when most companies had cash flow problems and large stocks of Kapenta in their warehouses. Therefore, faced with low demand and high supply the small emerging companies were forced to sell their Kapenta at lower prices than those offered in Kariba.

\subsection{The Impact of Company Size on Economic Performance}

Table 5 shows that the economic performance of different companies that are operating from Sanyati and Bumi.

Table 5. Average total costs and average marketing costs for 2010

\begin{tabular}{lcccc}
\hline Basin & \multicolumn{2}{c}{ Sanyati } & \multicolumn{2}{c}{ Bumi } \\
\hline Category & Small emerging & Big established & Small emerging & Big established \\
Average Total Cost & 3.81 & 4.32 & 4.03 & 4.58 \\
Average Marketing Cost & 0.14 & 0.322 & 1.06 & 1.01 \\
\hline
\end{tabular}

\subsubsection{Technical Economies of Scale of Production}

Contrary to the hypothesis that, big established companies have lower average total cost, small emerging companies exhibited statistically low average costs (using $t$ statistics) in both basins for as shown in Table 5 above. Palfreman and Lovland (1993)'s time series study also found that small emerging companies (majority of 
which are cooperatives) exhibited increasing economies of scale. They concluded that economies of scale were due to specialization of labour. That is, most cooperative members were specialized in specific jobs necessary to run a Kapenta fishing company. The principle behind cooperatives was that members had to pool resources (financial and human) together in order to benefit from economies of scale. In most of these cooperatives, there were qualified and experienced bookkeepers, mechanics, welders, experienced skippers and administrators who had prior experience in Kapenta fishing operations.

The above findings and those from Palfreman and Lovland's study seemed to contradict the theory that says, as companies grow in size the average unit cost of production would be reduced. This seemed to support empirical evidence that small firms were more efficient than large firms in developing countries (Moyo, 1995). In fact, this argument was typically advanced as one of the arguments for land reform that supported small-scale operations. However, there were several factors that could be used to explain this unexpected trend within the Kapenta fishing industry.

The argument of labour specialisation seemed to contradict our observations, which were also voiced by some managers of established fishing companies. Observations, especially in Bumi were that most of these cooperatives failed to work on the principle of cooperatives as the government envisaged they would where people with talent in a particular area formed a cooperative to make use of talent and specialisation. Taylor and Collins (2000) and Bhatnagar (2007) note that attracting talent is critical survival of the business yet all the cooperatives employed people to work on their behalf who were their relatives and not that talented. A wife of one company manager who was sitting besides her husband during the interview interjected and said;

'Gilbert used to be our best fishermen. He used to catch a ton of fish per night. When he left our company to join a co-operative, I thought the cooperative would benefit from his expertise and experience. The last time I saw him, he told me that he does not go into the Lake to fish as the cooperative had employed some people to fish on their (members') behalf.'

In most cases, cooperative members employed their relatives and family members. This shows lack of the strategy to engage and retain talent in the business (Manimala and Bhati, 2011) and turning to nepotism, employing relatives of whom it was observed that these were unwilling to respond to the same discipline as others and they tended to demand special treatment. According to Schneider, Smith, and Sipe (2000), organizational climate is viewed by employees as a source of embedded knowledge about how things are to be done and prioritized. This kind of climate created by employing kinsmen by the cooperatives functions as a source of situational cues used by employees as guidelines about how they want to work and how they are expected to behave (Ashkanasy, Wilderom, and Peterson 2000). Platteau (2000) also observes that in Sub-Saharan Africa norms of generosity make many proprietors fail to resist kinship demands thus end up employing incompetent relatives, which militates against the emergence of successful entrepreneurs.

High death rate, mainly due to HIV/AIDS and Malaria resulted in deaths of many cooperatives members. It therefore means that there was a high staff turn over rate. The expertise of the original members assumed by Palfreman and Loveland were no longer in the cooperatives. Teaching new members on how to fish, mend nets and to dry Kapenta took time as most of the heirs, (of cooperative membership) were inexperienced. If there was no labour specialisation among most cooperatives, what factors then accounted for a higher return to scale among cooperatives?

It could be that the low average costs were a result of companies' ability to control expenses. Small emerging companies (especially cooperatives) had the capacity to catch large quantities of Kapenta at a lower cost. They did this by concentrating their operations along closed areas that were closer to their premises. These areas are reserved for Kapenta to breed and hence fishing in prohibited. Baumol (1990) and Holcombe (2002), point out that, entrepreneurship may be harmful. The ethical climate in these small organizations is such that they can fish in these closed areas, and reduce on operating costs (especially fuel) and catch small Kapenta that are abundant in these areas at the same time threatening the sustainability of the resource with no qualms about their impact and ethics (Ambrose, Arnaud, and Schminke, 2007; You, Jong-sung, and Khagram 2005). While economies of scale could be used to measure the performance of the fishing industry, it did not give consideration to how the good performance was impacting on the resource.

It is also possible that high average production costs among big established companies could be explained by theft of Kapenta. Tong, Alessandri, Reuer, and Chintakananda (2008) show that industry effects play an important role in explaining any variation in the value. In the fishing industry in Zimbabwe it was estimated that 30 percent of total catch is sold before it was landed (ZZSFP, 1997). One operator noted that during drought, the number of illegal buyers tended to increase. This was largely because labour demands in farmlands would be very low. This 
left the employed youth with few options other than to engage in illegal buying and selling of Kapenta before it is landed. The most vulnerable were the companies that employed crew to fish for them. Cooperatives that use members had low incidents of their Kapenta being sold before it was landed.

\subsubsection{Marketing Economies of Scale}

Marketing costs included mainly transport costs associated with delivering Kapenta to the first customer. Table 5 shows that marketing costs is a very small percentage of total revenue. Nevertheless, these varied by size and location, with companies in remote areas incurring higher marketing costs. In the past, Kapenta traders used to buy the product from company premises. The cheap Kapenta from Mozambique and the stolen Kapenta from Lake Kariba flooded the local Kapenta market. These factors depressed the demand of Kapenta from Kariba. Under these circumstances, it meant that companies had to be vigilant in securing markets for their Kapenta. Each company searched for a marketing system that was best suited to deal with problems that it was faced with. The choice varied with company size and location. Hence the marketing costs varied by location and size of the fishing companies. The percentage of total revenue accounted for by marketing costs increased with the size of fishing companies in Sanyati and vice versa for Bumi. Table 5 shows that as companies grow in size average marketing costs also increase in the Sanyati basin. Using economic theory, one could conclude that in Sanyati, as companies increased in size there were marketing diseconomies of scale while in Bumi economies of scale were realised with growth in company size.

\subsubsection{Same Location Different Sizes of Companies}

High average marketing costs among big established companies in the Sanyati Basin could be due social capital and business networks developed over the years. These established business networks allowed them to sell the bulk of their Kapenta to established wholesalers that were based in cities Harare, Kwekwe, and Bulawayo. The established companies established contractual agreements with major wholesalers. Under the agreement, the producer had to transport his own Kapenta to the wholesalers. Although marketing costs were high they were compensated for by relatively high prices that they would sell at to wholesalers. There seemed to be an inverse relationship between marketing costs and the price at which Kapenta was sold.

Small emerging companies in the Sanyati basin had very low average marketing costs as most of the Kapenta was sold at the company premises. As discussed earlier, this also accounted for low revenues received after selling their Kapenta. Although some of these companies expressed interest in securing markets in other urban areas, the poor social capital and lack of business networks prevented them from accessing more lucrative markets. These marketing contracts or networks described above were historically established contracts.

The manager of a big wholesaler in Harare argued that there were high transaction costs involved in; screening for trustworthy partners, obtaining information about prices and product quality and enforcing new contracts. He added that high transaction costs were also accentuated by the fact that these small emerging companies in most cases failed to supply the required orders in time. This forced many wholesalers to resort to dealing with a tight network of sellers. This left small companies with little choice other than to depend on small-scale traders who came to buy Kapenta (at landing price) for repacking; hence their marketing costs were very low.

\subsubsection{Comparing Average Marketing Costs of Companies Operating in Bumi}

High average marketing costs among big companies in Bumi were largely due to the poor road networks linking landing sites to the markets. These poorly maintained roads added to the cost of distribution. Very few Kapenta traders were prepared to incur additional costs traveling to remote areas such as Bumi when they could get Kapenta from the Kariba. Big established companies in remote areas such as Bumi transported their Kapenta to their own retail and wholesale outlets in urban areas. These established companies employed experienced people with specialized expertise in both production (based within the fishing area) and marketing (based in urban areas) aspects of business management. Access to urban markets did not only increase the prices (see Table 3) of Kapenta and dampened seasonal price fluctuations but also increased marketing costs.

Emerging companies had a high average transport costs as they used mostly public transport (both water and land based) to ferry their Kapenta to nearby urban areas and growth points. They tended to ferry small volumes (that could be accommodated on bus) that were less profitable and sometimes delivered to unspecified markets. There were several factors that forced emerging companies to incur high average marketing costs. Firstly, the small-scale traders who came in the area bought small quantities of Kapenta. Most of these said that they mainly used income from agricultural sources, which was not predictable and highly dependent on the vagaries of weather. Cooperatives admitted that sales were good soon after a good agricultural harvest. The volume of trade depended on the amount of money available (to traders) when other responsibilities were met. Most of these 
traders were prepared to go into these areas because they could negotiate for low prices thus allowing them a disproportionately high mark up.

Secondly, when the emerging companies tried to enter into contractual agreements with wholesalers to buy all their Kapenta they faced difficulties. However, it was difficult for these small companies to produce a constant supply of Kapenta, as production was often disrupted breakdowns engines fitted of powering fishing boats. This probably could explain why wholesalers and retailers failed to make lasting marketing arrangements with cooperatives. At times, the small companies were forced to sell their Kapenta to established companies who had established markets in urban areas. Under this arrangement emerging companies received prices that were lower than the producer prices for their Kapenta.

\section{Conclusion}

State redistributed access rights to the resource without making efforts to level off differences in experience and skills between new entrants and established companies on how to deal with problems emanating from the macro economic environment and other institutional issues within the fishing industry. Failure to level off the disparities in business management skills and expertise, information gained through fishing and willingness to accept great risk could lead to variations in companies' performance.

The article has shown that the economic performance varied between new entrants and established companies depending on the investment in technical equipment and location of the fishing company. Variations in economic performance were due to the fact that some resource users had relatively large amounts of production factors, better skills and knowledge of the markets that enabled them to exploit and market the Kapenta efficiently. This advantage originated in past accumulation of wealth, greater social networks and business relations or privileged access to markets.

Relative poor performances among small companies and cooperatives in particular, was a result of unequalising mechanisms operating through historically established social and business relations. Established companies had better access to outside economic opportunities and they enjoyed better access to output markets because they possessed a relatively large amount of productive factors required for exploiting the fishery. Another explanation of the relative poor performance among small companies was their internal inadequacies to deal with challenges inherent within the fishery.

Technical economies of scale alone might not be enough to measure performance. Otherwise management decisions based on economies of scale alone might be misleading and detrimental to the resource. Emerging companies' shirking behaviour (resulting in catching juvenile Kapenta) could cause stock externalities that might make big companies targeting mature Kapenta to suffer in the long run.

\section{References}

Ambrose, M. L., Arnaud, A., \& Schminke, M. (2007). Individual Moral Development and Ethical Climate: The Influence of Person-Organization Fit on Job Attitudes. Journal of Business Ethics, 77(3), 323-333. http://dx.doi.org/10.1007/s10551-007-9352-1

Ashkanasy, N. M., Wilderom, C., \& Peterson, M. (2000). Handbook of Organizational Culture and Climate. Retrieved from http://espace.library.uq.edu.au/view/UQ:145716

Baumol, W. J. (1990). Entrepreneurship: Productive, Unproductive, and Destructive. Journal of Political Economy, 98, 893-919. http://dx.doi.org/10.1086/261712

Bhatnagar, J. (2007). Talent Management Strategy for employee engagement of Indian ITES employees: key to retention. Employee Relations, 29, 640-663. http://dx.doi.org/10.1108/01425450710826122

Burt, S. L., \& Sparks, L. (2003). Power and competition in the UK grocery market. British Journal of Management, 14(3), 237-254. http://dx.doi.org/10.1111/1467-8551.00377

Cinquini, L., \& Mitchell, F. (2005). Success in Management Accounting: Lessons from the Activity-Based Costing/Management Experience. Journal of Accounting \& Organizational Change, 1, 63-78. http://dx.doi.org/10.1108/18325910510635290

Coase, R. H. (1960). The problem of social cost. Journal of Law and Economics, 3, 1-44. http://dx.doi.org/10.1086/466560

Government of Zimbabwe. (1981). Growth with Equity: An Economic Policy Statement, Government Printers. Harare, Zimbabwe.

Holcombe, R. (2002). Political Entrepreneurship and the Democratic Allocation of Economic Resources. Review 
of Austrian Economics, 15, 143-159. http://dx.doi.org/10.1023/A:1015758419984

Kaplan, R. S., \& Cooper, R. (1998). Cost and Effect: Using integrated cost systems to drive profitability and performance. Boston, MA: Harvard Business School Press.

Manimala Mathew, J., \& Bhati, A. (2011) Talent Acquisition and Retention in Social Enterprises: Innovations in HR Strategies. Indian Institute of Management Bangalore. WORKING PAPER NO: 328

Nelson, B. S., \& Robinson, E. (2009). Critical Success Factors of a Whole Business Extension Approach for Increased Capacity of Beef Producers and Improved Enterprise Profit and Sustainability. Rangeland Journal, 31(1), 61-68. http://dx.doi.org/10.1071/RJ08059

Palfreman A., \& Lovland, J. (1993). An Economic Assessment of the Lake Kariba Kapenta fishery in Zambia and Zimbabwe, Zambia Zimbabwe SADC Fisheries Project, Report Number 14.

Platteau, J, P. (2000). Institutions, Social Norms and Economic Development. Harwood Academic Publishers. Amsterdam.

Porter, M, E. (1990). The Competitive Advantage of Nations. New York: Free Press.

Sam, M. (1995). The Land Question in Zimbabwe. National Printing Package, Harare, Zimbabwe.

Schneider, B., Smith, D. B., \& Sipe, W. P. (2000). Personnel selection psychology: Multilevel considerations. Multilevel theory, research, and methods in organizations: Foundations, extensions, and new directions. San Francisco, CA, US: Jossey-Bass.

Taylor, M., \& Collins, C. J. (2000). Organisational recruitment: enhancing the intersection of theory and practice. In C. L. Cooper, \& E. A. Locke (Eds.), Industrial and Organizational Psychology, Linking theory and practice (pp. 304-334). Basil Blackwell Oxford. http://dx.doi.org/10.1038/73737

Tong, T. W., Alessandri, T. M., Reuer, J. J., \& Chintakananda, A. (2008). How much does country matter? An analysis of firms 'growth options'. Journal of International Business Studies, 39, 387-405. http://dx.doi.org/10.1057/palgrave.jibs. 8400355

Varian, H. R. (1996). Intermediate Microeconomics. Norton, New York.

Williamson, O. (1996). The Mechanisms of Governance. Oxford: Oxford University Press.

You, J. S., \& Khagram, S. (2005). Comperative Study of Inequality and Corruption. American Sociological Review, 70(1), 136-157. http://dx.doi.org/10.1177/000312240507000107

Zambia Zimbabwe SADC Fisheries Project. (1997). Working Group on Bio-economic Assessment of Kapenta (Limnothrissa miodon) in Lake Kariba, Zambia Zimbabwe SADC Fisheries Project, Report Number 50. 